\title{
Anteseden Dari Family Satisfaction Serta Dampaknya Terhadap Hospital Image (Studi Pada Pelayanan Di Kamar Jenazah Dan Pemulasaran Jenazah Pada Rumah Sakit Swasta Tipe "B")
}

\author{
Evi Untoro,Ferdi Antonio \\ Fakultas Kedokteran Universitas Trisakti, Jakarta, Indonesia \\ Graduate School of Management, Universitas Pelita Harapan, Jakarta, Indonesia \\ evi_untoro@yahoo.com
}

\begin{abstract}
Abstrak
Rumah sakit swasta bersaing dengan cara mengupayakan kualitas pelayanan yang dapat memenuhi berbagai kebutuhan konsumennya. Salah satu unit pelayanan di rumah sakit yang sering terabaikan adalah pelayanan di ruang jenazah dan pemulasaraan jenazah. Keluarga dari jenazah tentunya ingin jenazah orang yang dicintai diperlakukan dengan hormat dan sebaik-baiknya sebelum dimakamkan. Penelitian ini terkait dengan faktor-faktor yang dapat berpengaruh pada kepuasan konsumen pada pelayanan tersebut masih jarang ditemukan. Tujuan penelitian ini untuk menguji pengaruh dari administration process, corpse transport dan hygiene and safety pada pelayanan dari mortuary clerk dan perawat pada family satisfaction, serta dampaknya pada hospital image. Metode penelitian: penelitian terapan, rancangan potong lintang, sampel 162 diambil secara purposive sampling, data diperoleh dengan mengisi kuesioner dari penelitian ini secara online. Analisis menggunakan PLS-SEM. Hasil penelitian menunjukkan bahwa dari ketiga anteseden proses, serta variable mediasi mortuary clerk dan perawat mempunyai pengaruh positif yang signifikan pada family satisfaction. Pengaruh paling kuat didapatkan dari administration process dan hygiene and safety. Sedangkan pengaruh langsung pada family satisfaction ditemukan paling kuat dari mortuary clerk. Ditemukan dampak positif dari family satisfaction terhadap hospital image, dengan demikian hasil penelitian ini mengkonfirmasi teori kepuasan konsumen dalam pelayanan kesehatan sekaligus menunjukkan aplikasi baru dalam pelayanan pengurusan jenazah (mortuary service). Model penelitian ini memiliki moderate predictive accuracy serta medium predictive relevance sehingga dapat dikembangkan dalam penelitian lebih lanjut. Terdapat implikasi manajerial dari temuan penelitian ini serta rekomendasi bagi penelitian selanjutnya.

Kata kunci: family satisfaction, hospital image, anteseden, pelayanan kamar jenazah dan rumah sakit swasta.
\end{abstract}


Abstract

Private hospital should provide excellent healthcare service to win the competition on the all aspect of services. One of the services that may ignored is the mortuary and mortuary service by the hospital. It is common that the family or relative want the corpse from their beloved person is well treated in a proper manner. However, there is lack of the research paper to explain which factors could influence the satisfaction of the family member toward the mortuary service at the hospital mortuary. To fill this gap, the research model has been modified from the previous literature in regard of consumer satisfaction in the healthcare facility. This study aims to investigate the influence of administration process, corpse transport, hygiene and safety factor on the service delivery by mortuary clerk and nurse on family satisfaction and its impact toward hospital image. Research method: applied research, crossectional design, 162 eligible sampling with purposive sampling. Data collected by questionare online. Analysis by PLS-SEM. Data collected from 162 eligible respondents that completely filled by online questionnaire. The result of the study demonstrated that all the three antecedents through the service delivery by mortuary clerk and nurse has the positive influence on family satisfaction. The strongest effect was found from administration process and the hygiene and safety factor, while the strongest direct effect on family satisfaction was found from mortuary clerk assistance. Further, family satisfaction is proven has a positive impact toward hospital image. Therefore it could be concluded that this study confirmed the theory of consumer satisfaction in the healthcare field, while offering the new insight of its applicability on the mortuary and mortuary service by the hospital. This empirical model has moderate predictive accuracy with medium predictive relevance, therefore it could be develop and test on the extended population. There are few managerial implications that could give suggestions for hospital managers to improve the service. Several recommendations also could be given for further research development.

Keywords: family satisfaction, hospital image, antecedents, mortuary service, and private hospital

\section{PENDAHULUAN}

Sistem kesehatan di dunia memungkinkan partisipasi pihak swasta sebagai mitra pemerintah dalam penyediaan pelayanan kesehatan bagi masyarakat umum sesuai dengan Sustainable Development Goals (SDGs) oleh Badan Kesehatan Dunia (WHO, 2020). Di Indonesia, pihak swasta dapat berperan aktif dalam pelayanan kesehatan (healthcare service) sekaligus mengembangkan bisnisnya dalam industri kesehatan. Peran pemerintah bertindak sebagai regulator dan penjamin mutu

pelayanan kesehatan dengan mengatur kebijakan pada bidang kesehatan, menetapkan standar pelayanan kesehatan, melakukan pengawasan teknis pada sektor bisnis kesehatan milik swasta (Kemenkes, 2020). Rumah sakit (RS) swasta mempunyai fungsi sosial dalam pelayanan dan mendapatkan keuntungan finansial agar dapat terus bertumbuh. Pertumbuhan ekonomi di Indonesia disertai dengan peningkatan daya beli konsumen turut mendorong perkembangan industri RS 
swasta yang menarik untuk dijadikan topik penelitian.

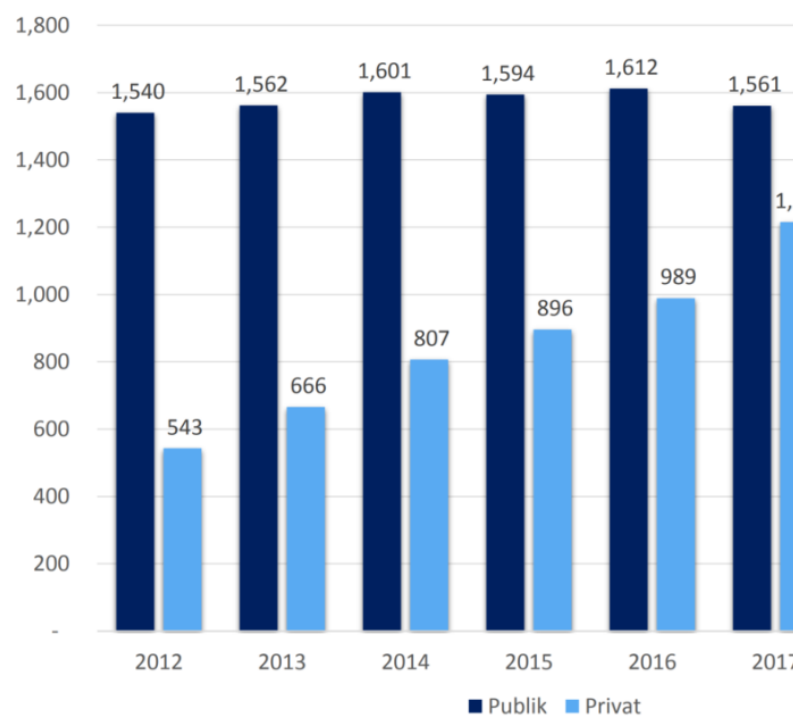

Grafik 1.1. Pertumbuhan RS Publik dan RS Swasta di Indonesia

Sumber: Kemenkes (2020)

Dari grafik, jumlah RS swasta di Indonesia bertambah setiap tahunnya dibandingkan dengan RS Pemerintah. Pertumbuhan mengindikasikan kebutuhan masyarakat akan pelayanan kesehatan yang berkualitas. RS swasta tumbuh dan bersaing melalui kualitas pelayanan yang diberikannya kepada konsumen dan bersedia membayar lebih karena kualitas pelayanan yang diterimanya (Andaleeb, 1998; Donabedian, 1988). Sehingga bisnis RS swasta di Indonesia mempunyai peluang berkembang, mendorong masuknya investasi dari dalam dan luar negeri, beberapa diantaranya telah go public di bursa saham, membuka lapangan kerja baru bagi tenaga kesehatan. DKI Jakarta, ibukota padat penduduk berpopulasi 11 juta jiwa per tahun 2019 , didukung oleh 133 RS swasta dalam melayani kesehatan, dengan jumlah 35 ribu tempat tidur telah memenuhi standar 1:1000 orang (Kemenkes, 2020) mengindikasikan jumlah RS di DKI Jakarta telah cukup banyak, sehingga persaingan RS swasta lebih kompetitif dan berusaha mempertahankan konsumen serta berlomba mendapatkan konsumen baru. Oleh sebab itu, RS di Jakarta dan sekitarnya dapat menjadi bahan analisis yang menarik dalam penelitian tentang manajemen RS. Dalam PERMENKES, setiap RS di Indonesia wajib terakreditasi, diakui mutu pelayanan kesehatannya melalui proses audit yang ketat menggunakan Standar Nasional Akreditasi Rumah Sakit (SNARS, 2017), satu fokusnya pada program peningkatan mutu dan keselamatan pasien (PMKP) dijabarkan indikator mutu sebagai alat ukur bagi evaluasi pelayanan di RS, terkait dengan standar kepuasan pasien atau konsumen RS. Manajemen RS swasta harus dapat memastikan bahwa kualitas pelayanan RS yang diberikan sesuai standar yang diatur pemerintah dapat memenuhi kepuasan pasien sehingga mempunyai sikap yang positif terhadap RS tersebut (Johnson, Russell, \& White, 2016; Wu, 2011), berpengaruh langsung terhadap niatnya untuk re-visit RS tersebut. (Kim, Shin, Lee, Lee, Kim, Choi, \& Ha, 2017), juga merekomendasikan RS tersebut pada orang lain (Fard, Sanayei \& Ansari, 2019). Dalam industri kesehatan rekomendasi ini menjadi alat promosi yang efektif. Jumlah kunjungan konsumen atau pasien yang meningkat dapat menjadi faktor penentu RS untuk bertahan dalam persaingan di bisnis RS (Arici \& Gucer, 2018) karenanya manajer RS harus memperhatikan semua aspek pelayanan di RS yang dapat berpengaruh pada kepuasan konsumennya.

Salah satu unit bisnis pelayanan RS bersentuhan langsung dengan konsumen dan sering diabaikan oleh Manejemen adalah pelayanan pada kamar jenazah terutama pada negara berkembang (Kazungu, Nanyingi, Katongole, Robert, \& Wampande, 2015), (Hallgrímur, Whitelaw, 
\& Indrojit, 2007). Padahal unit pelayanan ini mempunyai arti penting dalam kesehatan masyarakat (Joshi \& Joshi, 2009). Pada dekade terakhir ini telah banyak ditemukan upaya untuk meningkatkan pelayanan kamar jenazah (mortuary service) berserta fasilitasnya di RS (Sirohiwa, Paliwal, Sharma \& Chawla, 2011). Dari penelitian tersebut disebutkan bahwa perubahan perilaku konsumen saat ini menuntut pelayanan pada mortuary service sehingga harus didesain dengan lebih baik. Dapat dipahami bahwa konsumen ingin memberikan penghormatan terakhir sebelum jenazah dimakamkan, mereka ingin agar jenazah orang yang dicintainya diperlakukan dengan hormat, bermartabat dan dengan sebaik-baiknya. Penelitian empiris yang menyangkut pelayanan pemulasaraan jenazah (perawatan jenazah sehingga jenazah layak dan aman untuk dibawa keluarga) di kamar jenazah RS masih sangat terbatas jumlahnya karena sulitnya mendapatkan responden yang representatif. Keluarga jenazah umumnya dalam kondisi berduka yang dalam setelah kehilangan anggota keluarga yang dicintainya dan enggan untuk mengingat pengalaman yang sedih tersebut. Letak kamar jenazah di bagian belakang RS juga mengesankan kamar jenazah dan pelayananannya kurang penting. Namun di sisi lain hal ini dapat menjadi peluang untuk memberikan pelayanan yang dapat menimbulkan impresi atau kesan baik terhadap RS tersebut. Khususnya pada keluarga jenazah yang hadir, mendampingi atau mengurus proses perawatan jenazah hingga membawa pulang jenazah untuk dimakamkan dengan layak. Berdasarkan pertimbangan di atas, penelitian ini diharapkan dapat memberikan kontribusi baru dalam pelayanan perawatan jenazah di
RS yang berhubungan dengan kepuasan konsumen. Dimana teori-teori kepuasan pasien akan diimplementasikan dalam pelayanan di unit kamar jenazah rumah sakit. Karena pertimbangan etika medis penelitian ini hanya dibatasi pada jenazah dengan kondisi meninggal bukan karena sebab yang tidak wajar atau pasien yang terkonfirmasi oleh infeksi Covid-19 selama pandemi ini.

\section{METODE PENELITIAN}

Penelitian difokuskan pada RS swasta area DKI Jakarta dan sekitarnya, terakreditasi "B" paripurna (SNARS, 2019) telah melakukan pelayanan yang sesuai standar termasuk pelayanan pada kamar jenazah dan memiliki lebih banyak kamar (ruang perawatan) sehingga kemungkinan kasus kematian dan perawatan jenazah lebih banyak ditemukan di lingkungan bisnis kompetitif dalam kualitas pelayanan yang unggul, konsumen umumnya berada pada status sosial ekonomi menengah ke atas dengan tingkat pendidikan yang baik sehingga dapat memberikan gambaran akan harapan atau ekpektasi konsumen yang potensial. Berdasarkan teori health care quality diketahui bahwa outcome pelayanan dipengaruhi komponen struktur dan proses pelayanan itu yang merupakan hasil interaksi interpersonal antara pasien dengan penyedia layanan kesehatan. Faktor kompetensi petugas kesehatan, fasilitas dan proses komunikasi serta afeksi dari penyedia layanan merupakan determinan penting dalam kepuasan pasien di rumah sakit. Tiga faktor proses pelayanan langsung oleh petugas kesehatan diwakili variabel administration process, patient flow, dan patient safety; variabel penyedia layanan diwakili oleh variabel care provider dan nurse atau perawat. Dalam penelitian 
ini care provider dapat dikonversi menjadi mortuary clerk atau petugas kamar jenazah yang mempunyai kompetensi khusus dan termasuk sebagai petugas kesehatan. Model penelitian Johnson dan Russel (2015) mempunyai keterbatasan karena hanya mengunakan patient satisfaction sebagai variabel dependent yang diketahui belum menunjukkan intensinya di masa depan. Sedangkan intense atau perilaku di masa depan ini penting sebagai indikator kinerja RS (Fard et al, 2019; Kim et al., 2017). Hospital image juga terbukti mempunyai pengaruh signifikan pada patient loyalty (Asnawi, Awang, Afthanorhan, Mohamad, \& Karim, 2019). Penelitian Odoom, Narteh dan Odoom (2019) mengungkapkan pengaruh positif dari faktor branding serta proses pelayanan di RS terhadap hospital image. Kepuasan konsumen ini mempunyai pengaruh langsung yang signifikan terhadap hospital image (Karbalaei, Abdi, Malmir, Dehghanan, Pirnejad \& Jafar, 2013). Pada model penelitian ini variabel kepuasan konsumen diuji dampaknya pada hospital image sebagai variable dependent penelitian. Adapun peningkatan persepsi konsumen pada hospital image diketahui akan meningkatkan kinerja bisnis dari RS (Wu, 2011)

Dalam pelayanan kesehatan di RS, seringkali pasien dalam keadaan sakit, tidak sadar atau tidak dalam kondisi dapat menilai kualitas pelayanan yang diterimanya (lack of decision making capacity). Konsep proxy satisfaction (Castle, 2006) dimana kepuasan pasien dapat dinilai oleh keluarga, atau orang dekat yang mendampingi pasien tersebut selama proses perawatan di RS (surrogate role). Keluarga pasien dalam hal ini juga sebagai subjek yang menerima layanan kesehatan, misalnya mereka yang mendapat informasi atau instruksi dari petugas kesehatan di RS. Pengalaman yang diterima oleh keluarga pasien berpengaruh pada kepuasannya dan keputusan lebih lanjut melibatkan mereka dikenal sebagai family member's satisfaction. Konsep ini dapat diimplementasikan pada studi tentang kepuasan layanan perawatan purna pasien (pasien yang meninggal dalam perawatan di RS). Berdasarkan hal tersebut variable kepuasaan pasien dalam penelitian ini dikonversi menjadi variable kepuasan keluarga jenazah (family satisfaction).

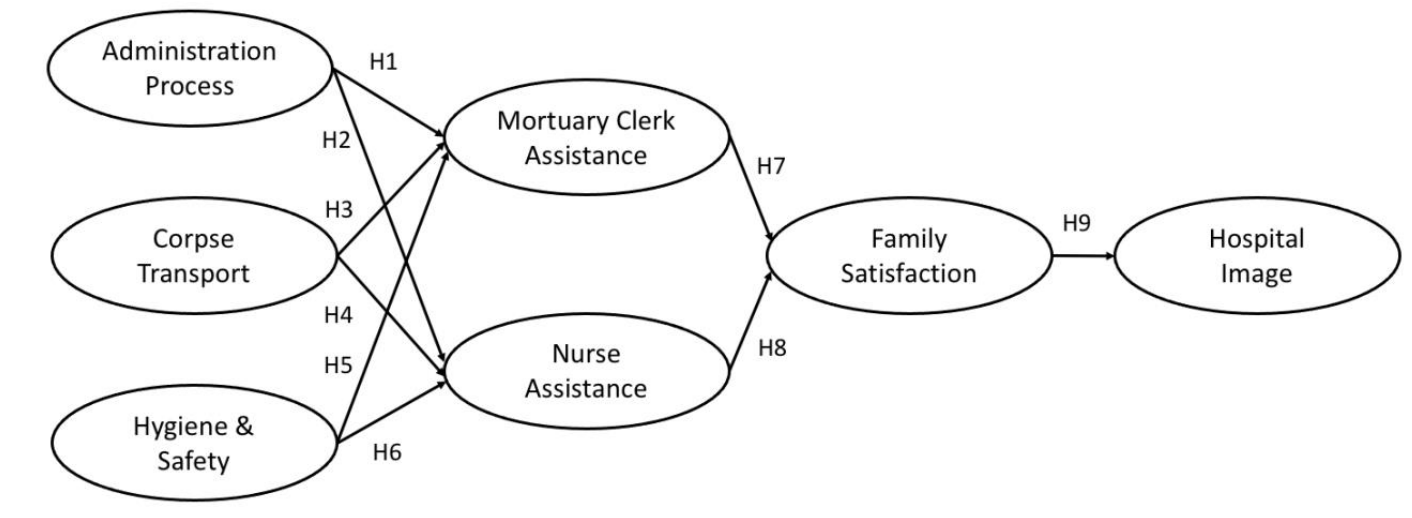

Gambar 2.1 Model Penelitian

Sumber :Modifikasidari Johnson \& Russel (2015), Karbalei et al (2013)

http://ejournal.urindo.ac.id/index.php/MARSI 
Posisi penelitian mengajukan suatu model penelitian baru yang dimodifikasi dari model penelitian terdahulu (Johnson \& Russel, 2015; Karbelei et al., 2013; Kim et al., 2017), diuji secara empiris pada keluarga jenazah yang menerima pelayanan di kamar jenazah dan pemulasaraan jenazah di RS swasta yang ada di Jakarta dan sekitarnya. Objek dalam penelitian ini adalah semua variabel yang termasuk di dalam model penelitian ini. Sebagai variable terikat atau dependent adalah hospital image sedangkan family satisfaction, mortuary clerk assistance dan nurse assistance sebagai variable mediasi. Unit analisis individual berasal dari individu yang diambil dari masing-masing responden merupakan keluarga dari jenazah yang meninggal di rumah sakit. Empat kriteria wajib responden yang harus dipenuhi: pertama, responden adalah keluarga dari jenazah yang menerima pelayanan pengurusan jenazah termasuk pemulasaraannya di RS swasta. Kedua, responden berada pada RS dan kamar jenazah saat membawa pulang atau memindahkan jenazah ke rumah duka. Ketiga, pelayanan pengurusan jenazah tersebut terjadi dalam satu tahun terakhir dari November 2020. Keempat, keluarga jenazah telah berusia lebih dari 17 tahun saat mengisi kuesioner. Tipe penelitian ini cross-sectional studies, kuantitatif dengan uji hipotesis (hypothesis test), korelasional (correlational), dan bukan bersifat kausalitas (sebab - akibat) antar variabel penelitian. Merupakan penelitian noninterventional artinya tidak ada perlakuan khusus atau intervensi yang dilakukan pada subjek penelitian selama periode penelitian. Dalam penelitian ini digunakan skala ordinal untuk menentukan perbedaan tiap konstruk dimana dimungkinkan mengkonversi data yang diterima dari responden melalui item pertanyaan kueisoner menjadi bentuk numerik atau dalam angka, menggunakan skala Likert responden dapat menyampaikan persetujuannya dengan lebih tepat untuk tiap pernyataan yang diajukan.

Tabel 3.1 Definisi Konseptual dan Operasionalisasi Variabel

\begin{tabular}{|c|c|c|c|}
\hline Variabel & DefinisiKonseptual & OperasionalisasiVariabel & $\begin{array}{c}\text { Sumber / } \\
\text { Skala }\end{array}$ \\
\hline $\begin{array}{c}\text { Administrati } \\
\text { on Process }\end{array}$ & $\begin{array}{l}\text { Proses transaksi dan } \\
\text { penyelesaiannya yang } \\
\text { terjadiberkaitandenganpelaya } \\
\text { nan } \\
\text { rumahsakit } \\
\text { (Johnson et al., 2016) }\end{array}$ & $\begin{array}{l}\text { 1. Komunikasiberlangsungdenganlancarsaatkeluargamengurusadminist } \\
\text { rasijenazah di RS ini } \\
\text { 2. Petugasadministrasi di RS } \\
\text { inimenunjukkankeinginanuntukmembantukeluargapasien } \\
\text { 3. Petugasadministrasimemberikaninformasi yang } \\
\text { jelastentangpengurusanjenazah }\end{array}$ & $\begin{array}{l}\text { Johnson } \\
\text { dan Russel } \\
\text { (2015) } \\
\text { Skala Likert } \\
\text { (1 sd 5) }\end{array}$ \\
\hline $\begin{array}{l}\text { Hygiene and } \\
\text { Safety }\end{array}$ & $\begin{array}{l}\text { Proses perawatan yang } \\
\text { meminimalkanresiko, } \\
\text { mengurangikemungkinankesal } \\
\text { ahan yang dapatmencederai } \\
\text { dan } \\
\text { merugikankeselamatanpasien } \\
\text { dan petugaskesehatan }\end{array}$ & $\begin{array}{l}\text { 1. Proses transport } \\
\text { sertaperawatanterhadapjenazahdilakukandenganmenjagakebersihan } \\
\text { 2. Petugasmenggunakanalatpelindung yang lengkap (masker, face } \\
\text { shield, sepatu boot dan sarungtangan) }\end{array}$ & $\begin{array}{l}\text { Modifikasid } \\
\text { ari Johnson } \\
\text { dan Russel } \\
\text { (2015); } \\
\text { Kazungu et } \\
\text { al, } 2015\end{array}$ \\
\hline
\end{tabular}




\begin{tabular}{c|cc} 
& (Johnson et al., 2016) & $\begin{array}{l}\text { 3. Lingkungank } \\
\text { cukupcahaya) }\end{array}$ \\
& & $\begin{array}{l}4 . \quad \text { Pelayanan p } \\
\text { (physical distancin }\end{array}$ \\
\hline $\begin{array}{c}\text { Varia- } \\
\text { bel }\end{array}$ & DefinisiKonseptual \\
\hline $\begin{array}{c}\text { Corpse } \\
\text { Transpo } \\
r t\end{array}$ & $\begin{array}{l}\text { Proses pemindahanjenazahdariruang di } \\
\text { rumahsakitmenujukamarjenazahsampaidenganpenyer } \\
\text { ahankepadakelaurga (Joshi \& Joshi, 2015; Depkes, } \\
\text { 2004) }\end{array}$
\end{tabular}
y Clerk Assistan ce

Petugaskamarjenazah di rumahsakit yang mempunyaikompetensi dan memberikanpelayanan (Kazungu et al., 2015; Joshi \& Joshi 2004)
Perawatprofesional di rumahsakit yang

Nurse

Assistan

ce memberikanpelayanan, dan berinteraksidenganpasien dan pihakkeluarga

(Otani et al., 2012)
OperasionalisasiVariabel

Sumber /

Skala

1. Proses

kepindahanjenazahmenujukekamarjenazahberlangsun glancar

2. Tidakadawaktutunggu yang lama untukmembawajenazahkekamarjenazah

Skala Likert (1 sd 5)

Modifikasi

dari

Johnson

dan

Russel

(2015) ;

Kazungu

et al.,

2015

3. Petugasmemindahkanjenazahkekamarjenazahdeng anbaiksertarapi

Skala

Likert (1

sd 5)

1. Petugaskamarjenazahmemperlakukanjenazahdeng anhormat

2. Petugaskamarjenazahmemilikiketrampilandalamm engurusjenazah (misalmemandikanjenazah)

Modifikasi

dari

Johnson

dan

Russel

(2015) ;

Kazungu

et al.,

3. Petugaskamarjenazahmenunjukkanempati pada keluargajenazah

2015

4. Petugaskamarjenazahmerespondengancepatbilaad apertanyaan

Likert (1

sd 5)

Modifikasi

1. Perawatmenunjukkansikapramahdenganberempat i pada keluargajenazah.

2. Perawatmemberikaninformasi yang

dari

Johnson

dan

Russel

(2015) ;

Kazungu

et al.,

(2015)

3. Perawatmemperlakukanjenazahdenganhormat dan bermartabat

Skala

Likert (1

sd 5)

Sumber/S

kala

$\begin{array}{llll}\text { Variabel DefinisiKonseptual } & \text { OperasinalisasiVariabel } & \begin{array}{l}\text { Sumb } \\ \text { kala }\end{array}\end{array}$

$\begin{array}{cl} & \\ \text { Family } & \begin{array}{l}\text { Penilaianmenyeluruhdarikeluargapasienterhadappelay } \\ \text { Satisfac }\end{array} \\ \text { tion } & \text { rumanang diberikan oleh } \\ & \text { 1998; Frivold et al, 2016) }\end{array}$

1. Saya merasapuasdengankeseluruhanpelayanan $\mathrm{di}$ kamarjenazah dan pemulasaraanjenazah di RS ini

2. Pelayanan pada kamarjenazah dan pemulasaraanjenazah di RS inisudahsesuaiharapansaya

3. Saya merasabahwakeputusansayasudahtepatuntukmemilihl ayanankamarjenazah dan pemulasaraanjenazah di RS ini
Kim et al. (2017) : Johnson et al., (2016)

Skala Likert (1 sd 5) 
Relasikonsumendengan brand yang

Hospital dapatmenimbulkankesan, perasaaan, persepsi,

Image kepercayaan dan sikapterhadap brand tersebut. (Hsieh et al.,2004)

Sumber :Olahan penelitian (2020)

Populasi penelitian semua keluarga jenazah yang menerima pelayanan pada kamar jenazah dan pemulasaraan jenazah dari keluarganya di RS swasta yang ada di Jakarta dan sekitarnya.

Sampel penelitian keluarga jenazah yang menerima pelayanan pemulasaraan jenazah di RS swasta di daerah Jakarta dan sekitarnya. Pengambilan sampel tersebut dilakukan di bulan Oktober - November 2020 dalam kondisi pandemi Covid-19. Sampel penelitian tidak diambil dari kasus meninggal karena infeksi Covid-19 yang memerlukan protokol jenazah secara khusus dan ketat. Karena pertimbangan etika penelitian, tidak ditanyakan kepada keluarga jenazah tentang penyebab kematian dan tidak ditanyakan keluhan pasien apakah terkait dengan infeksi Covid19. Untuk menghitung jumlah sampel yang diperlukan pada populasi yang jumlahnya tidak diketahui, maka pada penelitian ini digunakan rumus proporsional (Lemeshow et al., 1990), dan berdasarkan pendekatan sampel minimal untuk metode Partial Least Square - Structural Equation Modelling (PLS-SEM) dari Kock dan Hadaya (2018), menggunakan metode penghitungan akar kuadrat terbalik (inverse square root method), sampel yang diperlukan minimal 160 responden memberikan hasil yang optimal dalam perhitungan dengan PLSSEM. Sampel Penelitian yang memenuhi syarat sejumlah 162 responden. Metode pengambilan sampel purposive sampling,
1. Rumahsakitinimempunyaireputasi yang baik

2. Saya percaya pada pelayanan di rumahsakitini

3. Pelayanan di rumahsakitinimengutamakankenyamanankonsumenny a

Kim et al. (2008) ; Karbale et al., (2013)

Skala Likert (1 sd 5) salah satu kriteria wajib responden adalah keluarga jenazah yang secara langsung berada pada lokasi RS, khususnya saat transport jenazah ke ruang jenazah, yang mengurus administrasi atau saat membawa pulang jenazah. Responden yang memenuhi kriteria secara sukarela bersedia sebagai responden penelitian maka pada yang bersangkutan akan dikirim link kuesioner yang dapat diisi secara online. Metode analisis data menggunakan analisis multivariate dikarenakan model penelitian yang diajukan cukup kompleks dan menggunakan variabel laten atau konstruk (Sekaran \& Bougie, 2016). Terdapat tujuh variabel dengan sembilan jalur serta terdapat tiga variabel mediasi. Diperlukan metode analisis yang dapat menguji pengaruh antar variable secara serentak atau simultan menuju ke variable terikatnya (independent) dari metode analisis multivariate dipilih menggunakan metode analisis PLS-SEM yang berbasiskan variance, digunakan karena, pertama: sifat analisisnya pengembangan teori dalam penelitian exploratory. Kedua: untuk menguji model penelitian apakah mempunyai kemampuan explanation dan predictive pada penelitian ini untuk pengembangan lebih lanjut. Ketiga: tidak mensyaratkan input data yang terdistribusi secara normal. Metode analisis PLS-SEM dilakukan dengan aplikasi SmartPLS ${ }^{\text {тM }}$ versi 3.3., selain mempunyai menu dasar juga mempunyai menu advance (Ringle et al., 
2015) untuk analisis yang lebih dalam. Ouput model kalkulasi PLS-SEM dijalankan secara bertahap akan menghasilkan dua jenis model. Pertama, outer model / model pengukuran (measurement model). Ditampilkan hubungan antara indikatorindikator sebagai variable manifest dengan variabel latennya, menguji reliabilitas dan validasi dari indikator sebagai alat ukur konstruk dalam suatu model penelitian. Reliabilitas dilihat dua penilaian yaitu indicator reliability dengan melihat nilai outerloading dan construct reliability dengan melihat nilai Cronbach's alpha dan composite realibility. Uji validitas dilihat dua penilaian pula yaitu construct validity dengan melihat average variance extracted (AVE), dan discriminant validity dengan melihat nilai heterotrait-monotrait ratio (HT/MT). Apabila ke-empat parameter tersebut telah memenuhi syarat reliabilitas dan validitas maka barulah dapat dilanjutkan ketahap analisis berikutnya. Kedua, inner model / model struktural (structural model), ditampilkan hubungan antara konstruk dalam model penelitian. Untuk menilai kualitas model penelitian dan menguji signifikansi pengaruh antara konstruk disertai dengan analisis koefisiennya. Inner model / model structural merupakan model yang dapat menunjukkan hubungan antar variabel laten dalam suatu model penelitian. Tahap pertama melihat kualitas model nilai variance inflation factor (VIF) untuk menilai ada tidaknya masalah multikolineritas. Selanjutnya nilai koefisien determinasi atau $\mathrm{R}^{2}$ untuk menentukan kemampuan explanatory dan prediksi model yang diajukan untuk diuji empiris. Nilai $\mathrm{R}^{2}$ berkisar dari 0 hingga 1 dimana nilai yang lebih tinggi akan menunjukkan tingkat akurasi prediksi yang lebih tinggi. Menurut
Hair et al., (2019) nilai $R^{2}$ bisa dibagi menjadi tiga tingkatan yaitu $0,75,0,5$, dan 0,25 sebagai substantial, moderat dan lemah. Langkah selanjutnya dengan menilai $Q^{2}$ atau predictive relevance untuk memvalidasi kemampuan prediksi suatu model bila terjadi perubahan data. Apabila nilai $\mathrm{Q}^{2}$ predict lebih dari nol, maka dikatakan bahwa model structural memiliki prediksi yang relevan bila terdapat perubahan pada data yang digunakan dalam analisis. Sebaliknya jika nilai $\mathrm{Q}^{2}$ predict kurang dari nol maka menunjukkan bahwa model penelitian tidak memiliki prediksi yang relevan. Setelah dilakukan evaluasi model penelitian maka dilanjutkan dengan tahapan terpenting yaitu tahap pengujian hipotesis. Tahapan ini didapatkan dari menu bootstrap atau re-sampling pada SmartPLS ${ }^{\text {TM }}$ dengan melihat dua penilaian. Pertama dengan menguji signifikansi hubungan antara variable dengan menggunakan perbandingan nilai T-tabel dengan T-statistic. Jika T-statistic nilainya lebih tinggi dibandingkan nilai T-tabel, maka pengaruh variable tersebut dikatakan signifikan. Dalam penelitian ini digunakan tingkat signifikansi $\alpha=0,05$, dengan degree of freedom digolongkan infinity maka nilai T-tabel untuk uji satu sisi (one-tailed test) adalah 1,645 (Chin, 1988). Selanjutnya dengan melihat nilai koefisien yang dihasilkan melalui bootstrapping. Bila diketahui bahwa terdapat pengaruh yang signifikan dan arah koefisien yang telah sesuai dengan hipotesis maka dapat disimpulkan bahwa hipotesis didukung (supported). Setelah pengujian hipotesis tersebut dapat dilakukan analisis jalur atau path lebih untuk menganalisis kekuatan jalur yang melalui variable mediasi. Hal ini dilakukan untuk melihat juga kemampuan 
mediasi dari variabel-variabel mediasi yang ada dalam model penelitian. Analisis ini dapat dilakukan dengan melihat nilai specific indirect. Tahap terakhir yang dapat dilakukan dalam analisis dengan SmartPLS ${ }^{\mathrm{TM}}$ adalah dengan menu IPMA atau Importance Performance Map Analysis (IPMA). Analisis ini menggabungkan analisis deskriptif yang menggunakan nilai mean dengan analisis inferensial dengan menggunakan nilai total effect. Gabungan data tersebut digambarkan dalam peta atau mapping dengan dua axis dimana HASIL

Dari 162 responden yang memenuhi kriteria penelitian dengan gambaran profil responden sebagai berikut.

Tabel 4.1 Profil Demografi Responden

\begin{tabular}{|c|c|c|c|}
\hline Deskripsi & Kategori & Jumlah & Persentase (\%) \\
\hline \multirow{5}{*}{ Usia } & $<20$ tahun & 0 & 0 \\
\hline & 21 - 30 tahun & 21 & 13 \\
\hline & $31-40$ tahun & 70 & 43 \\
\hline & $41-50$ tahun & 53 & 33 \\
\hline & $>50$ tahun & 18 & 11 \\
\hline \multirow{4}{*}{ JenisKelamin } & Total & 162 & 100 \\
\hline & Pria & 77 & 48 \\
\hline & Wanita & 85 & 52 \\
\hline & Total & 162 & 100 \\
\hline \multirow{3}{*}{$\begin{array}{l}\text { Pendidikan } \\
\text { Terakhir }\end{array}$} & SMA/Sederajat & 26 & 16 \\
\hline & S1/D3 & 104 & 64 \\
\hline & S2/S3 & 32 & 20 \\
\hline Deskripsi & Kategori & Jumlah & Persentase (\%) \\
\hline \multirow{6}{*}{ Domisili } & Jakarta & 71 & 44 \\
\hline & Bogor & 20 & 12 \\
\hline & Bekasi & 25 & 15 \\
\hline & Tangerang & 28 & 17 \\
\hline & Lainnya & 18 & 11 \\
\hline & Total & 162 & 100 \\
\hline \multirow{2}{*}{ Pekerjaan } & Profesional & 21 & 13 \\
\hline & Karyawanswasta & 77 & 48 \\
\hline
\end{tabular}

posisi variabel dan indicator dapat dipetakan dalam gambar tersebut (Sarstedt, 2017). IPMA membantu menemukan faktor apa yang perlu ditingkatkan (improvement) misalnya karena sudah dianggap penting namun belum menunjukkan kinerja yang baik dan sebaliknya. Dengan demikian IPMA memberi masukan manajerial hal-hal apa yang harus diprioritaskan oleh manajemen RS. 


\begin{tabular}{clcc} 
& Pegawainegrisipil & 13 & 8 \\
Wiraswasta & 26 & 16 \\
Ibu rumahtangga & 17 & 10 \\
Lainnya & 8 & 5 \\
& Total & 162 & 100 \\
& Muslim & 93 & 57 \\
& Kristen & 25 & 15 \\
& Katolik & 22 & 14 \\
& Budha & 13 & 8 \\
& Hindu & 5 & 3 \\
& Konghucu & 2 & 1 \\
& Lainnya & 2 & 1 \\
& Total & 162 & 100 \\
\hline
\end{tabular}

Sumber: Hasil pengolahan data penelitian (2020)

Berdasarkan tabel di atas menunjukkan bahwa responden terbagi antara yang berusia muda dengan yang berusia paruh baya, diperkirakan sudah mempunyai kematangan emosional. Keluarga yang mengurus administrasi jenazah tidak didominasi oleh gender tertentu. Latar belakang mayoritas pendidikan terakhir setingkat sarjana dan pascasarjana, dianggap mampu memahami pertanyaan kuesioner dengan baik. Pekerjaan didominasi pekerjaan sebagai karyawan swasta, wiraswasta dan professional mengindikasikan umumnya mempunyai penghasilan tetap, dengan daya beli yang cukup baik dan mencari pelayanan yang berkualitas, tidak segan mengeluarkan uang untuk layanan yang berkualitas namun juga bersikap kritis bila ada pelayanan yang tidak sesuai dengan harapannya. Di era digital ini responden tersebut juga ditandai dengan penggunaan media sosial atau jaringan sosial online untuk berkomunikasi dan mengekpresikan perasaan atau berbagi pengalamannya. Apabila responden menerima pelayanan kamar jenazah yang kurang sesuai harapannya, mungkin saja

keluhan terhadap RS tidak disampaikan langsung namun diekspresikan dalam media sosial. Karenanya, manajemen RS perlu lebih memperhatikan kebutuhan dan perubahan perilaku konsumen seperti ini. Sebaran domisili responden didominasi oleh responden yang bertempat tinggal di Jakarta, diikuti oleh Tangerang dan Bekasi. Hal ini sesuai lokasi RS swasta yang menjadi lokasi penyebaran kuesioner yaitu RS Carolus, RS Siloam, RS Husada, RS PGI Cikini, RS Hermina, RS Mitra Keluarga dan RS Sentra Medika Cibinong. Pemilihan RS dipengaruhi oleh lokasi RS yang dekat dengan domisili responden atau keluarganya. Agama atau kepercayaan dari jenazah dan keluarga jenazah didominasi oleh responden yang beragama Islam, diikuti Kristen Protestan, dan Katolik sesuai dengan mayoritas pemeluk agama yang ada di Indonesia. Informasi terkait agama dari jenazah ini diperlukan untuk memberi pelayanan dan pemulasaraan pada kamar jenazah yang sesuai dengan agama yang dianut jenazah dan keluarganya merupakan hal sensitif mengikuti tata cara ibadah agama juga memperhatikan tradisi-tradisi 
yang ada, misal dalam proses pemandian jenazah harus dilakukan oleh petugas yang berjenis kelamin sama. Dengan demikian informasi profil konsumen dapat memberikan masukan bagi manajemen dalam mempersiapkan fasilitas sesuai agama keluarga jenazah dan menyusun rencana pemasaran $\mathrm{RS}$, misalnya melalui komunitas sosial atau keagamaan yang berada dalam pemukiman sekitar lokasi RS. Dari ke-tiga indikator administration process, menunjukkan kinerjanya masih dapat ditingkatkan lagi hingga masuk dalam kategori sangat setuju, terutama aspek pelayanan kesediaan petugas untuk membantu keluarga jenazah, dimana mereka memerlukan dukungan moril, simpati serta kesabaran dari petugas administrasi. Dari ke-tiga indikator Corpse Transport menunjukkan kinerja proses persiapan dan transport jenazah dari ruangan menuju ke kamar jenazah telah berlangsung dengan baik sesuai prosedur. Keluarga jenazah memberikan nilai kategori yang maksimal pada proses pelayanan ini, termasuk tidak dijumpai proses transport yang lambat. Dari ke-tiga indikator hygiene and safety dilihat dari nilai Indikator berisikan persepsi terhadap kebersihan kamar jenazah dan lingkungannya perlu mendapat perhatian lebih lanjut. Manajemen RS perlu memantau kondisi kamar jenazah dan fasilitasnya misalnya memperhatikan kontrol terhadap aroma atau bau, kondisi ruangan yang kering dan tidak lembab serta ventilasi dan penerangan yang cukup. Dalam kondisi pandemi Covid19 protokol kesehatan yang ketat perlu juga diberlakukan pada ruang jenazah. Dari masukan responden petugas di RS telah

Tabel 4.13.Discriminant Validity menggunakan alat pelindung yang lengkap (masker, face shield, sepatu boot, apron dan sarung tangan). Hal ini perlu terus menerus diperhatikan untuk melindungi petugas dan pengunjung di kamar jenazah. Dari ke-tiga indikator mortuary clerck assistance dilihat dari indikator berisikan empati petugas terhadap keluarga jenazah perlu diwaspadai karena dapat mempengaruhi penilaian kepuasan konsumen terhadap RS. Persepsi keluarga jenazah terhadap pelayanan oleh petugas kamar jenazah dalam hal memperlakukan jenazah dengan hormat serta mempunyai keterampilan merawat jenazah telah berkinerja baik dan perlu dipertahankan. Dari ke-tiga indikator nurse assistance dilihat dari nilai indikator kinerja perawat masih perlu diwaspadai karena masih ada konsumen yang memberi penilaian kurang setuju. Dapat dikatakan penilaian responden terhadap citra RS cukup merata. Secara keseluruhan persepsi keluarga jenazah terhadap pelayanan oleh perawat RS yang telah masuk dalam kategori sangat setuju ini perlu dipertahankan. Dari ke-tiga indikator family satisfaction di atas bila dilihat dari nilai secara keseluruhan kategori setuju ini masih perlu ditingkatkan menjadi kategori sangat setuju. Dari ke-tiga indikator hospital image dilihat dari secara keseluruhan kinerja RS yang telah masuk dalam kategori sangat setuju ini seperti pada reputasi dan persepsi bahwa RS telah mengutamakan konsumennya perlu dipertahankan. Indikator citra RS yang terkait dengan kepercayaan keluarga jenazah secara keseluruhan perlu menjadi perhatian lebih lanjut bagi manajemen RS dan dapat ditingkatkan melalui pelayanannya. 


\begin{tabular}{|c|c|c|c|c|c|c|}
\hline Variabel & 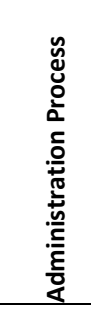 & 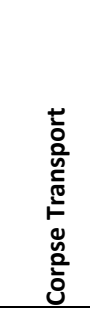 & 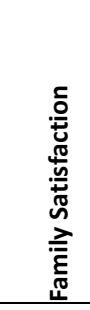 & 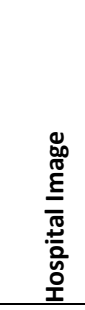 & 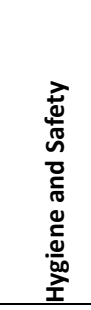 & 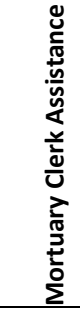 \\
\hline Corpse Transport & 0,645 & & & & & \\
\hline Family Satisfaction & 0,737 & 0,702 & & & & \\
\hline Hospital Image & 0,838 & 0,786 & 0,805 & & & \\
\hline Hygiene and Safety & 0,653 & 0,748 & 0,611 & 0,801 & & \\
\hline Mortuary Clerk Assistance & 0,768 & 0,652 & 0,685 & 0,818 & 0,644 & \\
\hline Nurse Assistance & 0,569 & 0,655 & 0,628 & 0,794 & 0,732 & 0,666 \\
\hline
\end{tabular}

Sumber: Hasil pengolahan data PLS-SEM penelitian (2020)

Pada tabel di atas dapat dilihat hasil uji discriminant validity dimana didapatkan nilai rasio heterotrait-monotrait (HT/MT) dari setiap variable di bawah 0,9. Berdasarkan data disimpulkan bahwa semua indikator pada model penelitian telah terdiskriminasi dengan baik sehingga dapat mengukur konstruknya masingmasing serta setiap indikator tersebut telah dengan tepat atau spesifik mengukur konstruknya masing-masing. Berdasarkan empat parameter hasil pengujian reliabilitas dan validitas pada outer model seperti diatas yaitu indicator reliability (outer loading), construct reliability (Cronbach's alpha dan composite reliability), construct validity (average variance extracted atau AVE), dan discriminant Tabel 4.18 Hasil Uji Hipotesis

No Path Coeffici-ent $\quad \begin{gathered}\text { Standardized } \\ \text { C-Statistics }\end{gathered}$

validity (heterotrait-monotrait ratio) dapat diambil suatu kesimpulan umum bahwa pada model pengukuran penelitian ini (measurement model) semua indicator telah reliabel dan valid untuk mengukur konstruknya masing-masing secara spesifik, dengan demikian layak untuk dilanjutkan dalam tahap analisis berikutnya yaitu uji inner model (model struktural).

Tahap selanjutnya uji signifikansi pada sembilan jalur atau path yang ada apakah signifikansi pengaruh antar variable dalam model penelitian sehingga dapat digeneralisir pada tingkat populasi. Dilakukan metode bootstrapping dengan resampling denganSmartPLS ${ }^{\mathrm{TM}} 3.3$ 


\begin{tabular}{|c|c|c|c|c|c|}
\hline H1 & Administration Process -> Mortuary Clerk Assistance & 0,451 & 5,573 & Signifikan & $\begin{array}{l}\text { Hipotesis } \\
\text { Didukung }\end{array}$ \\
\hline $\mathrm{H} 2$ & Administration Process -> Nurse Assistance & 0,153 & 1,847 & Signifikan & $\begin{array}{l}\text { Hipotesis } \\
\text { Didukung }\end{array}$ \\
\hline $\mathrm{H} 3$ & Corpse Transport -> Mortuary Clerk Assistance & 0,199 & 2,259 & Signifikan & $\begin{array}{l}\text { Hipotesis } \\
\text { Didukung }\end{array}$ \\
\hline $\mathrm{H} 4$ & Corpse Transport -> Nurse Assistance & 0,226 & 3,007 & Signifikan & $\begin{array}{l}\text { Hipotesis } \\
\text { Didukung }\end{array}$ \\
\hline H5 & Hygiene and Safety -> Mortuary Clerk Assistance & 0,165 & 2,109 & Signifikan & $\begin{array}{l}\text { Hipotesis } \\
\text { Didukung }\end{array}$ \\
\hline H6 & Hygiene and Safety -> Nurse Assistance & 0,427 & 6,265 & Signifikan & $\begin{array}{l}\text { Hipotesis } \\
\text { Didukung }\end{array}$ \\
\hline $\mathrm{H} 7$ & Mortuary Clerk Assistance -> Family Satisfaction & 0,379 & 6,616 & Signifikan & $\begin{array}{l}\text { Hipotesis } \\
\text { Didukung }\end{array}$ \\
\hline $\mathrm{H} 8$ & Nurse Assistance -> Family Satisfaction & 0,344 & 5,950 & Signifikan & $\begin{array}{l}\text { Hipotesis } \\
\text { Didukung }\end{array}$ \\
\hline H9 & Family Satisfaction -> Hospital Image & 0,704 & 18,493 & Signifikan & Hipotesis didukung \\
\hline
\end{tabular}

Sumber: Hasil pengolahan data PLS-SEM penelitian (2020)

Dari tabel hasil uji hipotesis diatas dapat diketahui bahwa dari Sembilan hipotesis dalam model penelitian yang diuji ditemukan kesemuanya signifikan dengan nilai koefisien yang positif sesuai dengan arah pada hipotesis yang diajukan. Uraian untuk masing-masing hipotesis dijelaskan dibawah ini.

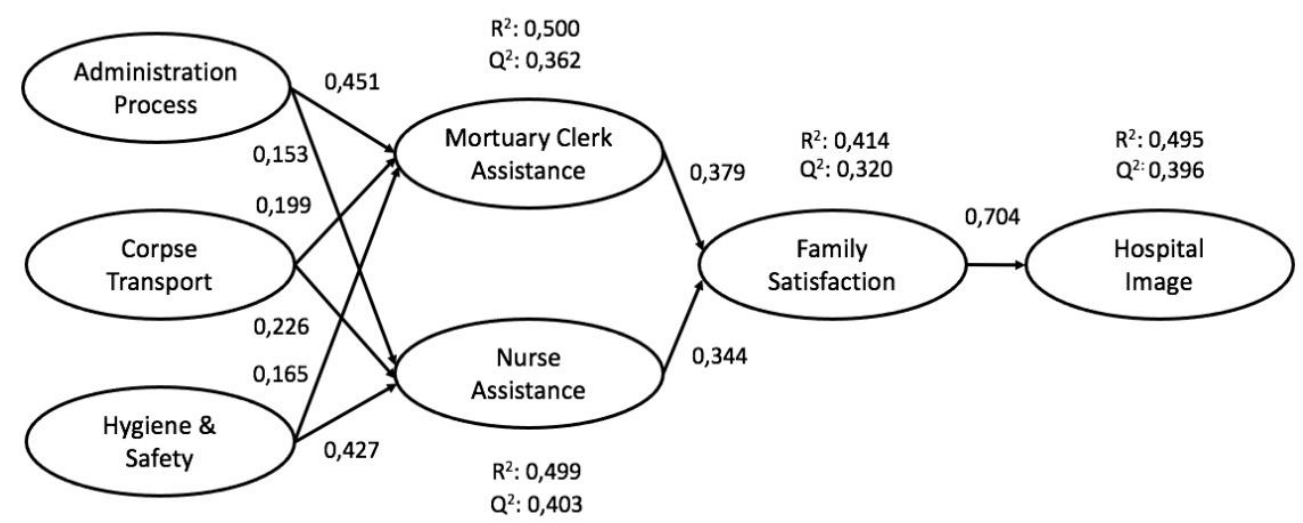

Gambar 4.9 Gambar Model Hasil (Empirical Model)

Sumber: Hasil pengolahan data PLS-SEM penelitian (2020)

Hasil analisis PLS-SEM pada model terbukti secara signifikan dengan penelitian dapat digambarkan seperti pengaruh positif sesuai dengan arah diatas sebagai model empiris (empirical hipotesis sehingga semua hipotesis dapat model). Dalam model hasil ini diketahui didukung (supported). Dengan demikian bahwa dari 9 jalur atau path kesemuanya model penelitian yang diusulkan ini dapat

http://ejournal.urindo.ac.id/index.php/MARSI 
diterapkan dan diuji pada populasi yang lebih cakupan geografisnya. Dari analisis model structural diketahui dari nilai $R^{2}$ dan $\mathrm{Q}^{2}$ bahwa model penelitian pelayanan rumah sakit ini mempunyai moderate predictive accuracy dengan medium predictive relevance pada variable dependen hospital image dan variable mediasi family satisfaction. Dengan demikian model penelitian ini juga dapat dikembangkan lebih lanjut dengan jumlah sampel yang lebih besar serta kriteria responden yang lebih ketat untuk mendapatkan model hasil yang lebih prediktif.

Tiga variabel-variabel independent dalam model ini mempunyai pengaruh signifikan, diketahui bahwa pengaruh paling kuat berasal dari administration process terhadap mortuary clerk assistance sebesar 0,451 diikuti oleh pengaruh dari hygiene and safety terhadap nurse assistance sebesar 0,427. Lebih lanjut pada analisis specific indirect effect juga ditemukan bahwa jalur yang paling kuat pengaruhnya dari variable independent menuju ke hospital image berasal dari administration process. Faktor yang berhubungan dengan kemudahan penyelesaian administrasi menjadi kebutuhan keluarga jenazah yang dalam kondisi berduka atau emosional setelah kehilangan anggota keluarganya, sehingga komunikasi dalam pengurusan administrasi ini perlu dilakukan dengan sikap empati. Diperlukan juga kinerja pelayanan yang memperhatikan faktorfaktor kebersihan (hygiene) beserta keselamatan pasien dan tenaga kesehatan (safety) terhadap persepsi konsumen, hal ini sejalan dengan hasil penelitian terdahulu. Kinerja tersebut juga relevan dengan dengan kondisi pandemi Covid-19 dimana protokol kesehatan yang ketat diberlakukan di RS. Temuan penelitian ini menunjukan pentingnya variabel-variabel tersebut untuk diprioritaskan dalam pelayanan pengurusan jenazah di RS swasta. Kedua variable mediasi baik dari petugas kamar jenazah (mortuary clerk) dan perawat (nurse) yang terlibat dalam proses transport serta pemulasaraan jenazah menunjukkan pengaruh yang signifikan terhadap kepuasan keluarga jenazah dan mampu memediasi pengaruh variable independent tersebut. Pengaruh positif kompetensi petugas di rumah sakit terhadap kepuasan keluarga jenazah tersebut mengkonfirmasi teori kepuasan pada layanan kesehatan (Andaleb, 1998; Johnson et al., 2016; Kim et al., 2017). Dari temuan ini peran petugas kamar jenazah dapat disejajarkan dengan healthcare provider walaupun obyek yang ditanganinya adalah jenazah (purna pasien). Kepuasan keluarga jenazah (family satisfaction) mempunyai dampak pada hospital image dengan koefisien 0,704 serta mampu memediasi pengaruh dari mortuary clerk dan nurse assistance. Temuan tersebut sejalan dengan penelitian terdahulu tentang pengaruh kepuasan terhadap hospital image (Marzaweny, et al., 2013; Karbalei et al., 2013; Odoom et al., 2019). Dengan demikian kepuasan pasien dalam penelitian tersebut dapat disejajarkan dengan kepuasan keluarga jenazah di rumah sakit sebagai proxy satisfaction (Castle, 2006). Temuan ini dengan setting atau konteks pelayanan di kamar jenazah dan pemulasaraan jenazah mengkonfirmasi teori bahwa kepuasan konsumen akan berdampak positif pada hospital image. Konsumen dalam hal ini keluarga jenazah tentunya ingin jenazah 
orang yang dicintainya diperlakukan dengan hormat, bermartabat serta diperlakukan sebaik-baiknya. Bila terpenuhi dapat mendorong kepuasan terhadap pelayanan RS. Ingatan bagaimana jenazah orang yang dicintainya diperlakukan di RS akan melekat di benak konsumen dan akan mempengaruhi persepsinya terhadap citra RS yang positif dapat mendorong loyalitas konsumen atau keinginan konsumen untuk merekomendasikan layanan RS tersebut (Wu, 2011; Asnawi et al., 2020). Karenanya pelayanan pada kamar jenazah dan pemulasaraan jenazah di RS menjadi hal yang penting diperhatikan oleh manajemen RS.

\section{KESIMPULAN}

Penelitian ini menggunakan model penelitian yang dimodifikasi dari penelitian terdahulu dengan hospital image sebagai variable dependen serta family satisfaction sebagai target construct. Dalam konteks pelayanan RS pada kamar jenazah dan pemulasaraan jenazah, hasil pengujian empiris dengan analisis PLS-SEM, didapatkan bahwa kesembilan hipotesis terbukti signifikan mempunyai pengaruh positif. Dari analisis model struktural diketahui bahwa model penelitian pelayanan RS ini mempunyai moderate predictive accuracy dengan medium predictive relevance pada variable dependen hospital image. Dengan demikian model penelitian ini dapat digunakan serta dikembangkan lebih lanjut pada penelitian selanjutnya. Pelayanan pengurusan jenazah sebagai bagian pelayanan RS juga mampu berkontribusi terhadap pembentukan citra positif RS. Manajemen RS dapat menawarkan program pelayanan kamar jenazah yang berkualitas dan berempati serta menyeluruh oleh petugas kamar jenazah beserta perawat di setiap touch point atau saat dimana terjadi kontak langsung dengan konsumen, didukung dengan fasilitas yang mudah, aman, dan nyaman. Fasilitas fisik pada kamar jenazah harus mendukung protokol kesehatan dalam pencegahan penularan virus Covid19. Kepuasan konsumen terhadap pelayanan pada kamar jenazah dan pemulasaraan jenazah mempunyai dampak yang nyata pada hospital image. Oleh karena itu manajer RS harus senantiasa memantau atau mengevaluasi kepuasan konsumen tersebut. Survei berkala konsumen RS oleh keluarga jenazah menjadi alat yang penting dimiliki manajemen untuk mendapat masukan langsung tentang hal apa yang perlu ditingkatkan dan dipertahankan, lalu mengevaluasi standar prosedur pelayanan RS yang telah disusun sesuai masukan konsumen tersebut. Pada akhirnya, konsumen yang puas akan memberikan penilaian positif terhadap citra RS, memberikan manfaat jangka panjang pada RS. Bila hospital image diceritakan pada orang lain maka dapat menjadi sarana promosi yang efektif bagi RS. Penelitian terkait topik pelayanan RS pada kamar jenazah tergolong jarang dilakukan karena tingkat kesulitan dalam mendapatkan responden yang representative dan di sisi lain, hal ini menjadi peluang untuk memberikan pelayanan yang dapat menciptakan kesan baik terhadap RS. Sehubungan dengan hal itu terdapat beberapa keterbatasan yang dapat ditemukan dari penelitian ini. Pertama, penelitian ini memiliki keterbatasan dalam cara penarikan sampel yaitu melalui kuesioner online yang dilakukan 
mengingat periode penelitian masih dalam kondisi pandemi Covid-19, kondisi responden yaitu keluarga dari jenazah tidak dapat diketahui dengan pasti dan sulit dilakukan konfirmasi. Kondisi faktor emosi atau mood saat akan mengisi kuesioner dapat mempengaruhi hasil. Hal lain adalah bahwa terdapat jarak waktu antara saat mengisi kuesioner dengan saat terakhir keluarga jenazah menerima layanan kesehatan pada kamar jenazah RS atau yang dikenal sebagai recall bias (Coughlin SS, 1990), disarankan dilakukan pengambilan data dan distribusi kuesioner pada responden yang dilakukan secara exit interview atau tatap muka langsung di RS. Hal ini dilakukan pada saat konsumen telah selesai menerima layanan di kamar jenazah, sehingga impresi terhadap pelayanan dapat langsung dicatat. Kedua, dari hasil analisis menunjukkan kemampuan prediksi model penelitian ini masih termasuk kategori moderate yang kemungkinan berkaitan dengan besar sampel. Sehingga dapat disarankan pada penelitian selanjutnya untuk menambah jumlah sampel serta dengan cakupan geografis yang lebih luas, misal dengan memasukkan RS swasta di kota besar lainnya sehingga dapat lebih mewakili populasi. Selanjutnya dapat disarankan pada penelitian selanjutnya dengan membuat kategori responden sesuai dengan jenis layanan kamar jenazah, misal pada kategori yang mendapat pelayanan khusus seperti pengawetan jenazah dengan formalin seusai dengan kebutuhan keluarga atau bila ada pelayanan pada kamar jenazah melibatkan keahlian tertentu dari dokter forensik. Hal tersebut diperlukan karena kebutuhan atau permintaan dari keluarga jenazah yang berbeda-beda. Perbedaan tersebut akan mempengaruhi penilaian terhadap kepuasaan responden saat mengisi kuesioner. Dengan membuat kategori tersebut diharapkan data dari responden serta kebutuhannya dapat dianalisis lebih mendalam dan menghasilkan temuan yang lebih spesifik.

\section{DAFTAR PUSTAKA}

1. Ampaw, E. M., Chai, J., Liang, B., Tsai, S.-B., \& Frempong, J. (2020). Assessment on health care service quality and patients' satisfaction in Ghana. Kybernetes, 49(12), 3047-3068. https://doi.org/10.1108/k-062019-0409

2. Andaleeb, S. S. (1998). Determinants of customer satisfaction with hospitals: A managerial model. International Journal of Health Care Quality Assurance,11(6), 181187. doi:10.1108/09526869810231541

3. Andaleeb, S. S. (2001). Service quality perceptions and patient satisfaction: a study of hospitals in a developing country. Social Science \& Medicine, 52(9), 1359$1370 . \quad$ https://doi.org/10.1016/s02779536(00)00235-5

4. Arici, C.N., \&Gucer, E. (2018). The Antecedents of Revisit Intention in Medical Businesses. Journal of Business Research - Turk. 10. 740-757. 10.20491/isarder.2018.453. (2018). The Antecedents of Revisit Intention in Medical Businesses. Journal of Business Research - Turk, 10(2), 740-757. https://doi.org/10.20491/isarder.28018.4

\section{$\underline{53}$}

5. Asnawi, A. A., Awang, Z., Afthanorhan, A., Mohamad, M., \& Karim, F. (2019). The influence of hospital image and service quality on patients' satisfaction and loyalty. Management Science Letters, 911920.

https://doi.org/10.5267/j.msl.2019.2.011 
6. Castle, N. G. (2006). Family Members as Proxies for Satisfaction with Nursing Home Care. The Joint Commission Journal on Quality and Patient Safety, 32(8), 452458. doi:10.1016/s1553-7250(06)32059-4

7. Carlucci, D., Renna, P., \&Schiuma, G. (2012). Evaluating service quality dimensions as antecedents to outpatient satisfaction using back propagation neural network. Health Care Management Science, 16(1), 37-44. https://doi.org/10.1007/s10729012-9211-1

8. Coughlin, S.S. (1990), Recall bias in epidemiologic studies, J Clin Epidemiol, 1990;43(1):87-

91.https://pubmed.ncbi.nlm.nih.gov/2319 285/, doi: 10.1016/0895-4356(90)90060-3.

9. Departemen Kesehatan Republik Indonesia (2004) Standar pelayanan Kamar Jenazah di RS.

10. Donabedian, A. (1988). The quality of care. How can it be assessed? JAMA: The Journal of the American Medical Association, 260(12), 1743-1748. https://doi.org/10.1001/jama.260.12.1743

11. Ekaterina, G. (2017). Measurement of Patient Satisfaction as a Quality Indicator of Hospital Health Services: The Case of Outpatient Clinics in General Hospital. Science Journal of Public Health, 5(2), 128. https://doi.org/10.11648/i.siph.20170502. $\underline{10}$

12. Frichi, Y., Jawab, F., \&Boutahari, S. (2020). Modeling the impact of hospital logistics on quality of care and patient satisfaction: Results of a survey in three public healthcare facilities in Fez, Morocco. Journal of Industrial Engineering and Management, 13(2), 296. https://doi.org/10.3926/jiem.3143

13. Frivold, G., Sletteb $\varnothing$, Å., Heyland, D. K., \& Dale, B. (2017). Family members' satisfaction with care and decision-making in intensive care units and post-stay follow-up needs-a cross-sectional survey study. Nursing open, 5(1), 6-14. https://doi.org/10.1002/nop2.97

14. Guo, Y., Zhou, Y., Xing, X., \& Li, X. (2020). Exploring the Relationship between Service Quality of Private Hospitals and Patient Loyalty from the Perspective of Health Service. Iranian Journal of Public Health, 1097-1105. https://doi.org/10.18502/ijph.v49i6.3361

15. Hair, J. F., Sarstedt, M., Hopkins, L., \& G. Kuppelwieser, V. (2014). Partial least squares structural equation modeling (PLSSEM). European Business Review, 26(2), 106-121. https://doi.org/10.1108/ebr-102013-0128

16. Hair, J. F., Risher, J. J., Sarstedt, M., \&Ringle, C. M. (2019). When to use and how to report the results of PLS-SEM. European Business Review, 31(1), 2-24. https://doi.org/10.1108/ebr-11-2018-0203

17. Hair, J. F., Howard, M. C., \&Nitzl, C. (2020). Assessing measurement model quality in PLS-SEM using confirmatory composite analysis. Journal of Business Research, 109, 101-110. https://doi.org/10.1016/i.jbusres.2019.11. $\underline{069}$

18. Hawthorne, G., Sansoni, J., Hayes, L., Marosszeky, N., \&Sansoni, E. (2014). Measuring patient satisfaction with health care treatment using the Short Assessment of Patient Satisfaction measure delivered superior and robust satisfaction estimates. Journal of Clinical Epidemiology, 67(5), 527537. doi:10.1016/j.jclinepi.2013.12.010

19. Henseler, J., Ringle, C. M., \&Sarstedt, M. (2014). A new criterion for assessing discriminant validity in variance-based structural equation modeling. Journal of the Academy of Marketing Science, 43(1), 
115-135. https://doi.org/10.1007/s11747014-0403-8

20. Johnson, D. M., \& Russell, R. S. (2015). SEM of service quality to predict overall patient satisfaction in medical clinics: a case study. The Quality Management Journal, 22(4), 18-36.

http://doi.org/10.1080/10686967.2015.11 918448

21. Johnson, D. M., Russell, R. S., \& White, S. W. (2016). Perceptions of care quality and the effect on patient satisfaction. International Journal of Quality \& Reliability Management, 33(8), 12021229. https://doi.org/10.1108/ijarm-082015-0121

22. Joshi, D., \& Joshi, M. (2009). Mortuary Services of Hospital. Hospital Administration, 369-369. doi:10.5005/jp/books/10358_48

23. Joshi, A., Kale, S., Chandel, S., \& Pal, D. (2015). Likert Scale: Explored and Explained. British Journal of Applied Science \& Technology, 7(4), 396-403. https://doi.org/10.9734/bjast/2015/14975

24. Kazungu, J., Miisa, N., Simon, PK., Anguyo, R., Lillian, NW. (2015) The State of Mortuary and Mortuary Services in Public Health Facilities of South Western Uganda. International Journal of Public Health Research. Vol. 3, No. 6, pp. 360-369

25. Kementerian Kesehatan Republik Indonesia. (2020). Diakses pada tanggal 20 Desember 2020: http://sirs.yankes.kemkes.go.id/fo/

26. Karbalaei, M., Abdi, A., Malmir, R., Dehghanan, H., Pirnejad, S., \& Jafari, S. (2013). Investigating of Brand Equity on Hospital Image. Research Journal of Applied Sciences, Engineering and Technology,6(20), 3888-3894. doi:10.19026/rjaset.6.3606

http://ejournal.urindo.ac.id/index.php/MARSI
27. Kim, C. E., Shin, J.-S., Lee, J., Lee, Y. J., Kim, M.-, Choi, A. \& Ha, I.H. (2017). Quality of medical service, patient satisfaction and loyalty with a focus on interpersonalbased medical service encounters and treatment effectiveness: a cross-sectional multicenter study of complementary and alternative medicine (CAM) hospitals. BMC Complementary and Alternative Medicine, 17(1), 1-12. https://doi.org/10.1186/s12906-0171691-6

28. Kock, N., \& Hadaya, P. (2016). Minimum sample size estimation in PLS-SEM: The inverse square root and gammaexponential methods. Information Systems Journal, 28(1), 227-261. https://doi.org/10.1111/isj.12131

29. Sirohiwa. I B. L., Paliwal, P. K., Sharma, L., Chawla, H. Design and Layout of Mortuary Complex for a Medical College and Periphera Hospitals. J Forensic Res, (2011) Vol. 2:6 102e. doi:10.4172/21577145.1000102e.

30. SNARS (2019). Standar Nasional Akreditasi Rumah Komite Akreditasi Rumah Sakit: Edisi 1.1.

31. Lemeshow, S., Hosmer, D. W., Klar, J., \& Lwanga, S. K. (1990). Adequacy of sample size in health studies. World Health Organization.

https://apps.who.int/iris/handle/10665/4 $\underline{1607}$

32. Marzaweny, D., Hadiwidjojo, D., \& chandra, t. (2013). Analisis Kepuasan Pasien sebagai Mediasi Pengaruh Kualitas Pelayanan Kesehatan terhadap Citra Rumah Sakit Umum Daerah (RSUD) Arifin Achmad Pekan baru. Jurnal Aplikasi Manajemen, 10(3), pp. 564-573. doi:http://dx.doi.org/10.18202/jam.v10i3. $\underline{448}$ 
33. Odoom, P. T., Narteh, B., \&Odoom, R. (2019). Healthcare branding: Insights from Africa into health service customers' repeat patronage intentions. International Journal of Healthcare Management, 1-13. doi:10.1080/20479700.2019.1688503

34. Otani, K., Kim, B. J., Waterman, B., Boslaugh, S., Klinkenberg, W. D., \&Dunagan, W. C. (2012). Patient Satisfaction and Organizational Impact: A Hierarchical Linear Modeling Approach. Health Marketing Quarterly, 29(3), 256269. doi:10.1080/07359683.2012.705724

35. Parasuraman, A., Zeithaml, V.A., \& Berry, L. (1988). SERVQUAL: A multiple-item scale for measuring consumer perceptions of service quality. Journal of Retailing, 64, 1240.

36. Prakash, G., \& Srivastava, S. (2019). Developing a Care Coordination Model Using a Hybrid DEMATEL and PLS-SEM Approach. IIM Kozhikode Society \& Management Review, 8(1), 34-49. https://doi.org/10.1177/22779752188129 $\underline{58}$

37. Robinaugh, D., McNally, R. (2013); "Complicated grief is associated with impairment in the ability to retrieve specific autobiographical memories."https://www.psychologicalscie nce.org/uncategorized/how-well-can-weremember-someones-life-after-theydie.html

38. Sarstedt, M., Ringle, C. M., \& Hair, J. F. (2017). Partial Least Squares Structural Equation Modeling. Handbook of Market Research, 1-40. https://doi.org/10.1007/978-3-319-05542$8 \quad 15-1$

39. Sekaran, U., \& Bougie, R. (2016). Research Methods for Business: A Skill Building Approach (7th ed.). Wiley.

http://ejournal.urindo.ac.id/index.php/MARSI
40. Sharma, V. (2017). Patient satisfaction and brand loyalty in health-care organizations in India. Journal of Asia Business Studies, 11(1), 73-87. https://doi.org/10.1108/jabs-09-2015$\underline{0157}$

41. Shmueli, G., Sarstedt, M., Hair, J. F., Cheah, J.-H., Ting, H., Vaithilingam, S., \&Ringle, C. M. (2019). Predictive model assessment in PLS-SEM: guidelines for using PLSpredict. European Journal of Marketing, 53(11), 2322-2347. https://doi.org/10.1108/ejm02-2019-0189

42. Undang Undang Pemilihan Umum Nomor. 7 tahun 2017, https://www.hukumonline.com/pusatdata /detail/lt59ba5511ab93b/node/534/unda ng-undang-nomor-7-tahun-2017

43. Vimla, \& Taneja, U. (2020). Navigating from Brand Image to Patient Loyalty: Mediating Effect of Service Quality and Patient Satisfaction. Journal of Health Management, 22(3), 430-445. https://doi.org/10.1177/09720634209379 $\underline{40}$

44. Wang, X., Chen, J., Burström, B., \&Burström, K. (2019). Exploring pathways to outpatients' satisfaction with health care in Chinese public hospitals in urban and rural areas using patient-reported experiences. International Journal for Equity in Health, 18(1), 442-449. https://doi.org/10.1186/s12939-019$\underline{0932-3}$

45. World Health Organization. WHO (2020). World Health Statistics 2020: Monitoring health for the SDG's - Sustainable Development Goals. Geneva: World Health Organization. https://apps.who.int/iris/handle/10665/3 $\underline{32070}$ 